\title{
RELATIONSHIP BETWEEN UNSAFE ACTION AND CONDITION WITH WORK ACCIDENT AMONG PRODUCTION UNIT WORKERS AT THE JAYA SENTRIKON INDONESIA COMMPANY, PADANG, WEST SUMATRA
}

\author{
Devina Lenggo Putri'), Sumihardi²), Asep Irfan²), I Made Djaja1) \\ ${ }^{1)}$ Department of Environmental Health, Faculty of Public Health, Universitas Indonesia \\ ${ }^{2}$ Study Program of Environmental Health, School of Health Polytechnics, \\ Ministry of Health Padang, West Sumatra
}

\begin{abstract}
Background: Work accident is a significant burden to society. Multiple factors contribute to work accident. Previous studies have focused on identifying individual and workplace contributing factors. Unsafe action and unsafe worksite may contribute to injury among workers. This study aimed to determine the relationship between unsafe action and condition with work accident among production unit workers at the Jaya Sentrikon Indonesia Commpany, Padang, West Sumatra.

Subjects and Method: This was a cross sectional study conducted at Jaya Sentrikon Indonesia Commpany, Padang, West Sumatera from September 2016 to Februari 2017. A sample of 50 workers was selected for this study. The dependent variable was work accident. The dependent variables were unsafe action and unsafe condition. The data were collected by a set of questionnaire and observation. The data was analyzed by a multiple logistic regression.

Results: $60 \%$ workers aged $>36$ years old. $100 \%$ workers were male. As many as $62 \%$ workers had experienced work accident. 50\% workers did unsafe action and $64 \%$ had unsafe condition. The risk of work accident increased with unsafe action (OR=24.43; $95 \% \mathrm{CI}=4.59$ to $130.01 ; \mathrm{p}=0.001)$ and unsafe condition $(\mathrm{OR}=11.26 ; 95 \% \mathrm{CI}=2.88$ to 43.93; $\mathrm{p}=0.001$ ).
\end{abstract}

Conclusion: The risk of work accident increases with unsafe action and unsafe condition.

Keywords: work accident, unsafe action, unsafe condition.

\section{Correspondence:}

Devina Lenggo Putri. Department of Environmental Health, Faculty of Public Health, Universitas Indonesia, Depok, West Java. Email: devinalenggo@gmail.com. Mobile: +6281268435893 . 